\title{
The Radical "Second Life" of Vilhjalmur Stefansson
}

The American Communist movement included numerous "front" organizations which championed the political views and advanced the goals of the Soviet Union. Among them were movements whose main aim was to provide support for the Soviet project to establish a Jewish socialist republic in the Birobidzhan region in the far east of the USSR. One of the organizations prominent in this campaign was the American Committee for the Settlement of Jews in Birobidjan. The Committee, also called Ambijan, was formed in 1934. It sought to attract to its ranks philanthropists and men of financial prominence or wealth. As well, it captured public attention through the recruitment of celebrities and fairly eminent public figures who, while not known Communists, were sympathetic to the politics of the USSR. Though their detractors called them "fellow-travellers," these people often proved to be valuable assets to the cause.

One champion of the Birobidzhan scheme, and a vice president of Ambijan after 1936, was the prominent Arctic explorer, scientist, and author Vilhjalmur Stefansson. A tireless proponent of settlement in Birobidzhan, he appeared at countless meetings, dinners, and rallies, recounting the exploits, real and imagined, of Jewish settlers trying to build a socialist republic in the tundra of the Soviet Far East. Given his fame and stature, he proved an invaluable resource for the leadership of Ambijan.

Born in 1879 in Arnes, Manitoba, a small Icelandic immigrant community in western Canada, Stefansson grew up in North Dakota. His various Arctic expeditions in Alaska and Canada, undertaken between 1906 and 1918, included the discovery of hitherto unknown islands. These expeditions, his ethnological descriptions of Inuit life in the Far North, and his tireless advocacy of the feasibility of northern colonization, both on the lecture circuit and in the corridors of power, made him a world-famous figure, and many of his books were best-sellers. Even so, many of his rivals and enemies, especially in Canada, tried to discredit him as a publicity-seeking charlatan, whose claims about the possibilities of life in the Arctic were overly rosy. In consequence, he suffered repeated rebuffs, which caused him great distress (Diubaldo, 1978). "If ever there was a prophet without honour in this country [Canada], it was Vilhjalmur Stefansson. A hero in the United States, he was persona non grata to many in Canada, especially those in official circles....his enemies in the civil service seem to have been almost pathologically inclined to oppose him" (Morrison, 1987:303).

The Soviets, however, adopted many of Stefansson's ideas and published his books in translation in the 1930s. He, in turn, began "extolling the achievements of the Soviets in the development of their northern regions, and making invidious comparisons as between Canadians and Americans, on the one hand, and the Soviets on the other" (LeBourdais, 1963:183-184). Soon enough, in the1930s, Stefansson, by now living in New York, became involved with various proSoviet political groups.
Stefansson was in particular impressed by Soviet efforts to open an Arctic sea route between the Atlantic and Pacific Oceans and by their expeditions to the North Pole. Soviet explorers, he noted, had been able to get ready support "from an Old World country where I failed in the New World" (Stefansson, 1937:8). When the Soviets unveiled their Arctic Pavilion at the New York World's Fair in 1939, Stefansson considered this "fitting, and most instructive to the United States and to Canada," since only the Soviet Union "carries forward the ideas and practices of frontier development." $\mathrm{He}$ added that "we are here to recognize what the whole world recognizes-the unquestioned leadership of the Soviet Union in the field of geographic exploration" (Stefansson, 1939:17-19).

After the Nazi attack on Russia in 1941, Stefansson immediately became active in the numerous Communist-led front groups organized to mobilize support for the USSR, giving his support to the American Council on Soviet Relations and Russian War Relief Inc., among others. As Jessica Smith (1943:21 -22), editor of Soviet Russia Today, said: "The Russians love and admire Stefansson. Given his propensity for combining pro-Soviet politics with expertise in far northern exploration and settlement, perhaps it was only natural that Stefansson would become linked to a project that involved the taming of a largely uninhabited wilderness at the far eastern edge of Siberia.

The notion that Birobidzhan might serve as a place of political refuge as well as a centre of Jewish economic and cultural regeneration had become more pronounced following Hitler's rise to power in Germany in 1933, and it would form the basis of Ambijan's work. The organization was conceived in 1934 by William W. Cohen, a former Democratic Congressman from New York and a prominent stockbroker and community worker. On 10 October 1935, Cohen sent Vilhjalmur Stefansson a letter outlining the goals of the Committee and informing him that "a number of prominent Jews and non-Jews" had already lent their names as sponsors (Stefansson Correspondence, MSS 196, Box 38, 1935).

Ambijan's literature stressed the need to select settlers who would need to be strong and healthy in order to adapt to Birobidzhan's climate and engage in physical labour. Stefansson disagreed; his own experiences in growing up on the frontier and afterwards working with people in the severe conditions of the Arctic had taught him that "good health and bodily strength, while desirable, are secondary. The chief thing is mental attitude.... What you need for Birobidjan, then, is not the physiologically hardy but the psychologically adaptable," people whose courage could not be broken. He urged Cohen to select families "who want to go, who think they are going to like it when they get there, and who expect to succeed." Cohen, impressed with the advice, invited Stefansson to his home on Central Park West to meet privately with a group of men interested in the project and also asked him to speak to an audience of "about 300 or 400 


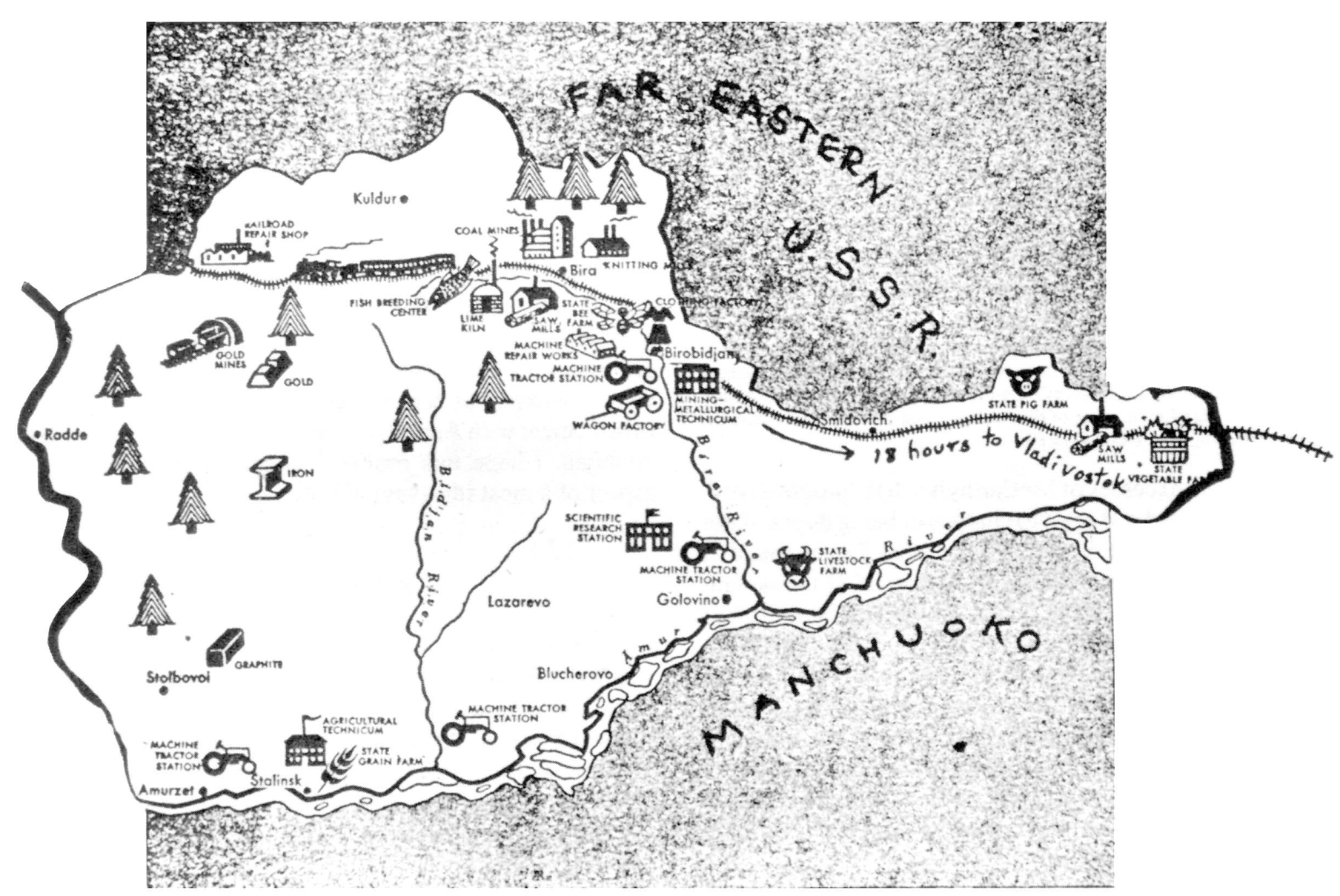

Map of Birobidzhan in 1944. Source: The Jewish Autonomous Region, U.S.S.R. 1944. New York: Ambijan Committee.

persons" at a forthcoming meeting; Ambijan wanted them to "understand that the problems of weather in Birobidjan, or, rather climate, can be easily answered by an expert" (Stefansson Correspondence, MSS 196, Box 40, 1936). Stefansson had found his role with Ambijan.

Ambijan produced a 50-page yearbook at the end of 1936, full of testimonials and letters of support. Among these was one from Stefansson, who was now also listed as a member of Ambijan's Board of Directors and Governors: "The Birobidjan project seems to me to offer a most statesmanlike contribution to the problem of the rehabilitation of eastern and central European Jewry" (Ambijan, 1936:6, 36). Birobidzhan was no utopia, Stefansson told an Ambijan meeting the following year, but for "the stricken Jews of Poland, Roumania, Lithuania, and other European countries, Birobidjan would already represent an advance to a higher standard of living, to say nothing of the immeasurably greater degree of security and hope for the future." His speech was carried on radio station WMCA in New York (Stefansson Correspondence, MSS 196, Box 43, 1937).

Ambijan was particularly active in the 1941-45 period, when the Soviet Union and the United States were allied in the war against Germany. In November 1941, Stefansson spoke at a dinner for Victor Fediushine, the Soviet consul general in New York. Max Levin, chair of Ambijan's Board of Directors, afterwards congratulated him on his "splendid address"
(Stefansson Correspondence, MSS 196, Box 56, 1941). Birobidzhan was "a sound contribution to the rehabilitation of eastern and central European Jewry," wrote Stefansson in 1944. "The policy of the Soviet Union, to make all racial and national minorities equal in practice as well as in theory, has given them a unity that has been one of the chief sources of their war strength..... On its tenth anniversary, Birobidjan is already a land of fulfilled promise" (Stefansson, 1944:1).

With the war drawing to a close, Ambijan held its first national conference in New York, on 25-26 November 1944. It was attended by 403 delegates from the United States, Canada, Mexico, and Cuba, along with a further 1000 guests. The conference pledged to raise $\$ 1$ million to support refugees in Stalingrad and Birobidzhan and to accelerate the industrial and cultural development of the Jewish Autonomous Region. Prominent guests and speakers included New York Congressman Emanuel Celler, Senator Elbert D. Thomas of Utah, and Soviet ambassador Andrei Gromyko. A public dinner, attended by the delegates and their guests, was hosted by Vilhjalmur and spouse Evelyn Stefansson. Vilhjalmur was selected as one of two vice presidents of the organization.

But the post-war climate proved destructive to Ambijan, and within a matter of years it would disintegrate. There was a sharp downturn in Soviet-American relations with the onset of the Cold War; domestically, the anti-Communist 


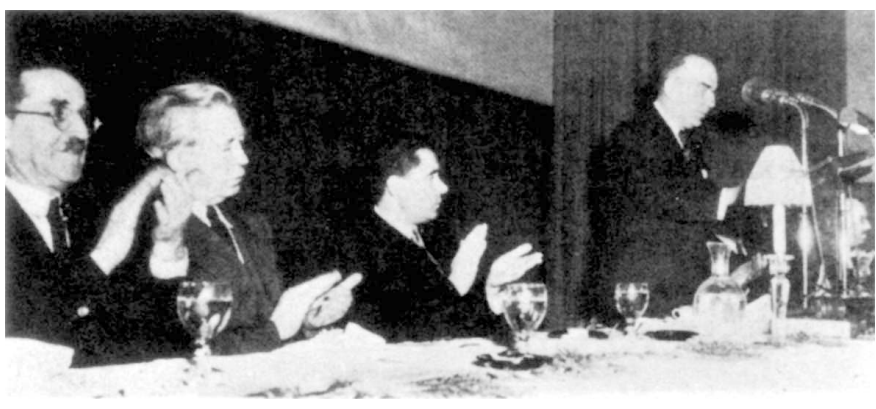

Ambijan dinner honouring Andrei Gromyko, Soviet Ambassador to the United States, held in New York on 25 November 1944. Left to right: J.M. Budish, chair of the Ambijan Administrative Committee; Vilhjalmur Stefansson; Andrei Gromyko; and Max Levin, chair of the Ambijan Board of Directors. Source: Ambijan Bulletin (June 1945) 4(1):19.

fervour and the excesses of McCarthyism left "progressives" politically exposed and open to charges of being dupes, if not indeed agents, of the Soviet Union. Max Levin found it necessary to write to Stefansson in October 1947 to reassure him about conditions in the Soviet Union and Birobidzhan (Stefansson Correspondence, MSS 196, Box 72, 1947). Ambijan held its final national conference in New York on 10-11 December 1949. The organization still retained 15000 members in 60 branches in 26 states, but it was no longer able to attract prominent politicians as keynote speakers. Stefansson was again duly elected as a vice president. In 1951, in the midst of the Korean War, Ambijan ceased operations.

Stefansson had been retained by the U.S. Office of Naval Research in 1946 to compile and publish a 20-volume Encyclopedia Arctica, which would have demonstrated Soviet superiority in the development of the Arctic. But he had not reckoned with the growing anti-Russian feeling in the country. "Exposés" of Stefansson began to appear in the press. In August 1951, he was denounced as a Communist before a Senate Internal Security subcommittee by Louis Budenz, a Communist-turned-Catholic (New York Times, 24 August 1951:8). Stefansson denied the charge, but soon thereafter, his work on the encyclopedia was terminated without explanation. No doubt the Navy had become uneasy about a man who continued to hold membership in Communist front organizations and who even, on occasion, had been known to contact the Soviet embassy (Hunt, 1986:257-258). The Stefanssons moved to Hanover, New Hampshire in December 1951, transferring their ever-growing library on the Arctic to Dartmouth College. Perhaps Stefansson himself had by then had some second thoughts about Ambijan, for his posthumously published autobiography (Stefansson, 1964) made no mention of his work on its behalf. Nor, for that matter, did his otherwise very complete obituary in the New York Times (27 August 1962:1, 23).

Vilhjalmur Stefansson was in many ways a man ahead of his time. For example, in an exchange of letters with engineer Philip Henry in September 1938, Stefansson informed Henry that the word Eskimo was a derogatory term used by Algonquins and had been borrowed by whites. He suggested that the Eskimos be referred to by their own term, Inuit
(Stefansson Correspondence, MSS 196, Box 44, 1938). He was, in any event, one of Canada's most prominent figures in the early decades of this century, so well regarded that his mere passage through a city made front-page news. Many books and article have been written about Stefansson's work in the Arctic; in 1965, the National Film Board of Canada produced a film entitled "Stefansson: The Arctic Prophet," written by his widow, Evelyn Stefansson Nef. Canada has even named an island in the Arctic for him. His eccentricities, such as his beliefs in the nutritional virtues of an all-meat diet, or his insistence that he had discovered "blond Eskimos" on one of his northern expeditions, have been widely noted. But next to nothing has been written about Stefansson's political involvement with American Communist front groups such as Ambijan. I hope this profile will shed some light on this aspect of a most idiosyncratic life.

\section{REFERENCES}

AMBIJAN, 1936. Birobidjan: A new hope for oppressed European Jews. New York: American Committee for the Settlement of Jews in Birobidjan.

DIUBALDO, R.J. 1978. Stefansson and the Canadian Arctic. Montreal: McGill-Queen's University Press.

HUNT, W.R. 1986. Stef: A biography of Vilhjalmur Stefansson, Canadian Arctic explorer. Vancouver: University of British Columbia Press.

LEBOURDAIS, D.M. 1963. Stefansson: Ambassador of the North. Montreal: Harvest House.

MORRISON, W.R. 1987. Review of Stef: A biography of Vilhjalmur Stefansson, Canadian Arctic explorer, by W.R. Hunt. Canadian Historical Review 68(2):303-304.

SMITH, J. 1943. On the Red Army's quarter century. Soviet Russia Today 11(12):21-23, 31.

STEFANSSON, V. 1937. A prophesy fulfilled. Soviet Russia Today 6(5):8.

1939. The friendly Soviet Arctic. Soviet Russia Today 8(4):17-19.

. 1944. 10th Anniversary Birobidjan. In: 10th Anniversary, Jewish Autonomous Region, May 1944. New York: 10th Anniversary Committee.

. 1964. Discovery: The autobiography of Vilhjalmur Stefansson. New York: McGraw-Hill.

STEFANSSON CORRESPONDENCE. 1935-1949. In the Stefansson Collection, Baker Memorial Library, Dartmouth College, Hanover, New Hampshire.

Henry F. Srebrnik Department of Political Studies University of Prince Edward Island Charlottetown, Prince Edward Island, Canada

C1A $4 P 3$ 